\title{
The Motif in Canadian Landscape Painting: From the Topographical to the Decorative
}

\author{
Lloyd James Bennett \\ Thompson Rivers University, Kamloops, Canada
}

\begin{abstract}
In Early 20th century, Canadian landscape painting had its roots in European art, especially in impressionism and subsequent developments. When Claude Monet took to working in a series to capture changing light, he sought to simplify his subject; the painter would focus on a motif: a passage of river, a tree, or a building facade. This editing out of landscape information led to a more abstract work where one might focus on the color or brushwork in the painting. This method led to a release from the task of measuring for accuracy for the viewer. Painting became sensory and not imitative where one was free to enjoy pure painting that spoke directly to a sensation or a delight in an unsuspected arrangement. At the end of the 19th century, Art Nouveau designs were printed in international journals, like The Studio and were studied in commercial design shops, like Grip Ltd., Toronto. The nucleus of Canada's leading painting group-the Group of Seven, was formed out of commercial art and, to some extent, designs one could see reproduced in magazines. Tom Thomson took these motifs; these abstracted forms and envisioned them in the landscape of Ontario through his plein air sketches. Lawren Harris stylized trees and mountain forms into abstractions of pure delight and A. Y. Jackson set his hills in the landscapes of rural Quebec where repeating rhythms trumped topography accuracy. This paper will highlight these Canadian painters as they introduced the motif that moved landscape painting to decoration of the most satisfying kind.
\end{abstract}

Keywords: landscape, painting, Canada, motif, plein air

\section{Introduction}

Landscape painting has had a long history where artists first recorded the animals and vegetation that made up the principle subjects of the land. While this representation varied from a row of deer painted over a rock ridge as at Lascaux Cave to a detailed perspective representation on the Arno River by Leonardo da Vinci, the need to respond to one's surroundings has always been present in art. The images of landscape in Canada largely followed those ideas and interests of the founding nations of Europe. Those military painters assignment to the British campaigns in the 18th century captured French fortifications along the St. Lawrence River introduced the topographical painting of watercolor art. The influence of Europe showed itself in early modernity when Canadian painters studied in Paris and Berlin incorporating this influence to the terrain of Ontario, Quebec, and the West. It was in the early 20th century that a unique Canadian landscape emerged in the future Group of Seven where the idea of a dominant feature emerged in these paintings. However, this feature, this motif of the landscape had a much earlier origin.

Lloyd James Bennett, Ph.D., associate professor, Visual and Performing Arts, Thompson Rivers University, Kamloops, Canada. 


\section{The First Motif-Argument for Eden}

The earliest example of a description of an aspect of landscape occurs in Genesis 3:3 when Eve tempted by the tree of forbidden fruit described it as "pleasant to the eyes". The tree was also the source of knowledge, which led to Adam and Eve becoming aware of their nakedness and their expulsion from the garden and eventual return to dust. There are two parts to the passage that define the role of the single tree or motif: The Garden of Eden was described as having many trees, which were good for food, but the Tree of Knowledge was singled out by God as not to be eaten from and that it was a tree "pleasant" to look at by Eve. Therefore, the proper viewing of this featured tree was solely to enjoy beauty and that learning, or instruction would be a distraction from the pure pleasure of viewing the tree. ${ }^{1}$

The medieval artist maintained this understanding for the Tree of Knowledge, revealing it as a decorative design of pure form. Here, there was nothing to be learned, but only a highly abstracted form to please the eye. Adam and Eve sit below the tree, as yet without clothes discussing their options, while God looks on from on high at his creation (see Figure 1). The motif of the tree becomes the focus of the image as it stands in advance of the serpent tempting Eve and the couple's eventual expulsion from paradise. This simplification would be overtaken by the renaissance painter who would take landscape along a naturalistic route that was directed to recording topography over promotion of a significant feature of landscape with a spiritual message.

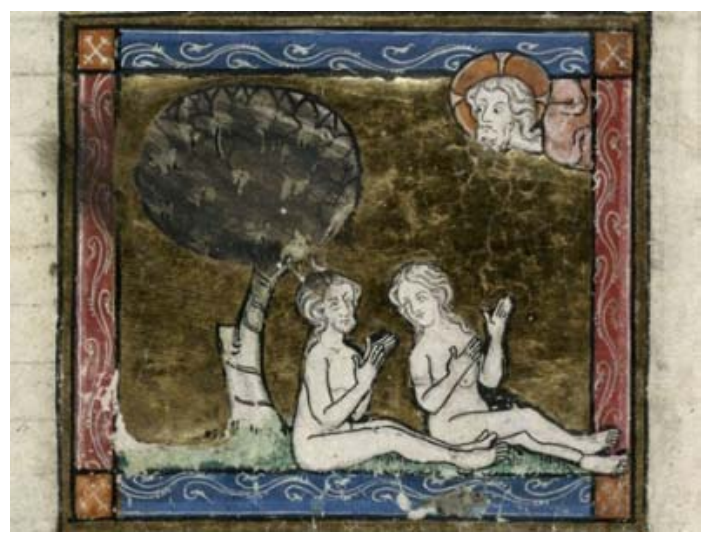

Figure 1. Medieval Tree of Knowledge (Bing).

\section{Topographical Measure}

The renaissance artists laid the format of a topographical landscape where trees and land formations, such as mountains, would diminish in size and rivers would meander back into space; the final depth cue would be the white of aerial perspective where the landscape illusion would be completed in deep space (see Figure 2). These cues became accepted devices to recreate a believable landscape into space, which required a measuring on the part of the viewer to determine the success of the picture. This "measuring" called for the viewer to make judgments as to accuracy within terms of the entire scene or space at the expense of focusing on an aspect of the landscape. It became a proposition of gaining knowledge rather than just looking for pleasure as the first beauty lover intimated what the special tree motif should provide.

\footnotetext{
1 The Bible makes use of features, or motifs of landscape, to carry messages such as the meaning of the rainbow as God's covenant with Noah (Genesis 9:8) or the message to Moses with the burning bush (Exodus 3:4).
} 


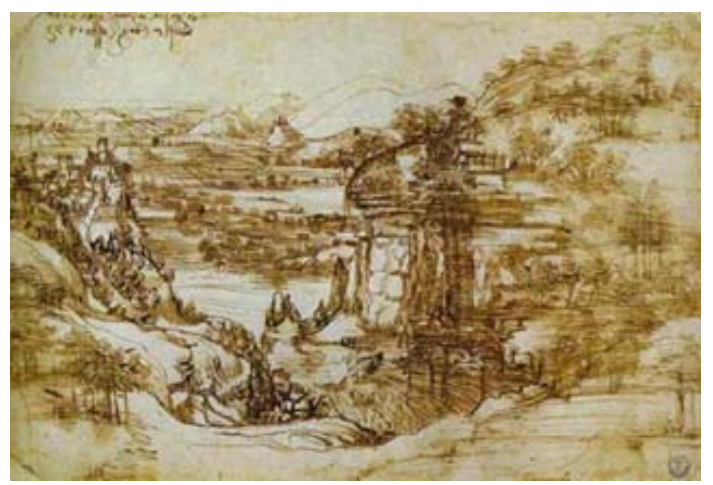

Figure 2. Arno landscape (Source: Leonardo da Vinci, 1473) (Bing).

The topographical picture provided information, which was the goal of the military artists who were assigned to Canada during The Seven Years War (1756-63). Trained at the Woolwich Military Academy ${ }^{2}$, Thomas Davies made accurate renderings of French fortifications, which assisted the British in their attacks along the St. Lawrence River (see Figure 3). Like the Renaissance artists who were looking for depiction of a specific place, the watercolor images were to provide information through correct recording in perspective the breadth of subject and the single item focus, as in the medieval motif, was not a consideration. Still, Davies could not limit himself to making just a record of the site, when he introduced in the foreground an officer fishing in the river forks while other boats with fishers apply the calm waters. This was the influence of the picturesque tradition, which scenic artist Paul Sandby brought to his teaching at the military school. The direct representation of a subject might be enhanced with these details or incidents that we suspect were not always present when the plein air artist looked at the prospect.

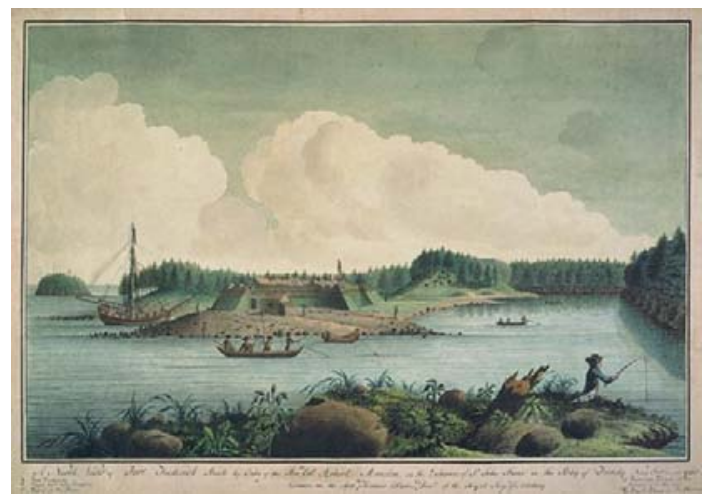

Figure 3. St. John River Campaign: The Construction of Fort Frederick (Source: Thomas Davies 1758).

\section{Return to Motif}

By the 19th century, painters were introducing new approaches into presenting landscape. Claude Monet

\footnotetext{
2 "Thomas Davies was born in 1737 from the Welsh origin. In 1755, Davies joined the Woolwich Academy and took drawing lessons. Woolwich Academy was founded by King George II in 1741 with the goal of producing 'good officers of artillery and perfect engineer' (The Academy: Your Peace of History). The focus of Woolwich Academy is the study of accuracy and detailed composition of objects since those aspects is needed for military records. During that time period (1768), Paul Sandby was appointed chief drawing master of the Royal Military College at Woolwich and he began to develop his technique and composition of drawing through combining topographical and picturesque elements in one painting (The Art of Paul Sandby, 1985, pp. 10-11). Davies picked up some of Sandby's technique to his drawing and developed this skill to advance his style". The Art of Thomas Davies. Retrieved October 5, 2018, from http://www.collections.musee-mcord.qc.ca
} 
reduced the depth cues in favor of a foreground motif that occupied most of the scene. At the arch at Etretat, which Monet painted many times from 1883 to 1885 (see Figure 4), he focused on the outer pier where he cuts the landscape with a colossal arc. Another arc formed from the sea and the sky complete an interlocking design fixed to the foreground, which overwhelms the cues of distance illusion. The stone rises out of the turbulent green sea in bands of pink and violet with swirls of white lapping up against the rock face. These tones loop in the distant sky favoring the cold/warm contrast of the cliff motif. Here, the brushwork moves everywhere as a surface of delicious mint and lilac fixed by the motif of the great arm of the rock set before a low horizon line. The painting moves a seascape from one of measuring into depth to one of delight in color and deft brushwork - the rewards of abstract art.

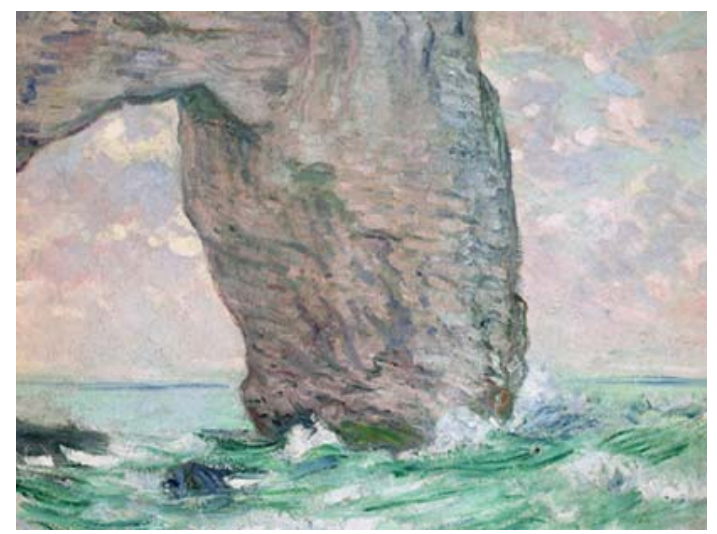

Figure 4. Stormy Sea in Etretat (Claude Monet, 1883-1885) (Bing).

\section{Designs in Nature}

No subject had engaged the Canadian artist Tom Thomson more than the tree. Joan Murray, who wrote a monograph on Thomson "tree" paintings, identified his situation for developing the motif in his works, "Thomson background in commercial design gave him decided advantages when he became an artist: One was the idea of reusing a motif, drawn from visual experience or memory, in different woks, thus giving access to an array of fresh starts" (Murray, 1999, p. 28).

After training in Seattle (Town \& Silcox, 1977, p. 51), Thomson went to work for the Grip Limited Company in Toronto where he developed his illustration skills through his acquaintance in the shop with established designers, like J. E. H. Macdonald and those available art journals, like the International Studio, published in New York, where the turn of the century art style that was having worldwide influence was Art Nouveau (see Figure 5). This modern movement, which had various names in Europe, determined to bring aesthetics to the public through abstracted forms from nature. Common characteristics of the style motifs on nature where the arabesque dominated commercial designs and found a foothold in fine art pictures. When Thomson went in the northern Ontario landscape, he developed a type of picture where he used the stylized, Art Nouveau-type tree placed before a middle distance. This had the effect to move the painting away from naturalism and diminishing space, to the decorative treatment of the tree overlapping a space enforcing a flattened design. 


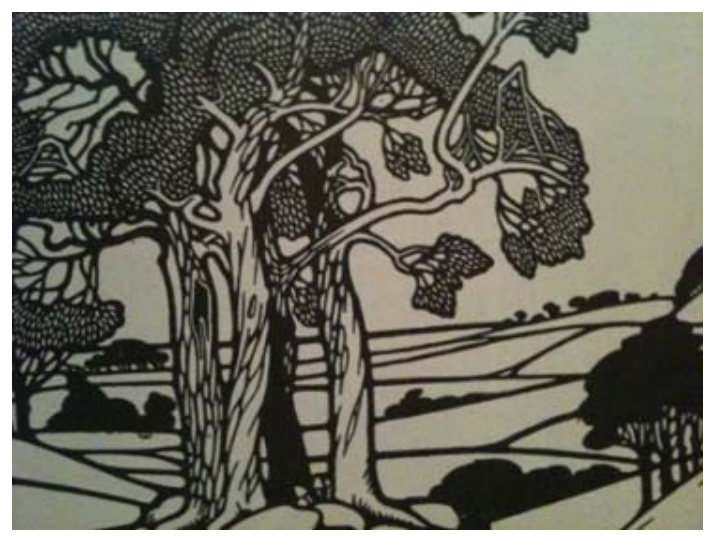

Figure 5. Art Nouveau trees (Bing).

There are many paintings from 1914 that reveal Thomson's design-based motif of the stylized tree set against a middle-distance view of a pool or a bank of rock formations. The Twisted Maple (see Figure 6) recalls the long Art Nouveau curve, but toughened by direct painting from the Algonquin parkland. The rough bark of the maple runs from the top of the panel to the bottom covered in places with splashes of orange-red and yellow ochre leaves pasted to the net of branches. A few strokes of a softened blue move beyond the foreground profusion, while a unity of vertical strokes set the distant bank. The foreground overlapping suggests the landscape space, but the juxtaposition of complementary colors (blue-orange and yellow-violet) and energetic brushwork make the painting operate on the surface where local areas are savored. The leaves are painted with a freedom where one tone mixes with a base coat to produce a chance blending of ragged leaves of luminous texture, the lower yellow ochre ones appear to droop from wind wear.

Thomson places as much importance on method as he does on subject. With each part of the painting, he discovers a method to paint that section: The distant bank becomes a band of vertical strokes of blue and grey tones; the sky continues the painterly brushwork with strokes of vermillion to light blue broken by stipple marks of white. The oil recalls a tapestry where the flourish of brushstrokes and patches hold the eye to the front of the picture. Each painting taken from the bush is considered a sketch, being done quickly engendering vitality that carries forth in the plein air situation. The scenes or prospects appear to come from a trail or from a canoe viewpoint. These are not "august sites" (to use Walter Sickert's term), but appear freshly discovered in the painter's exploration of nature. Yet, these are not generic trees but named species in their natural habitat where weather is always present. Jackson who painted with Thomson observed the effect of onsite painting, "He gave us the fleeting moment, the haunting memory of things he felt" (Jackson, 1967, p. 33). 


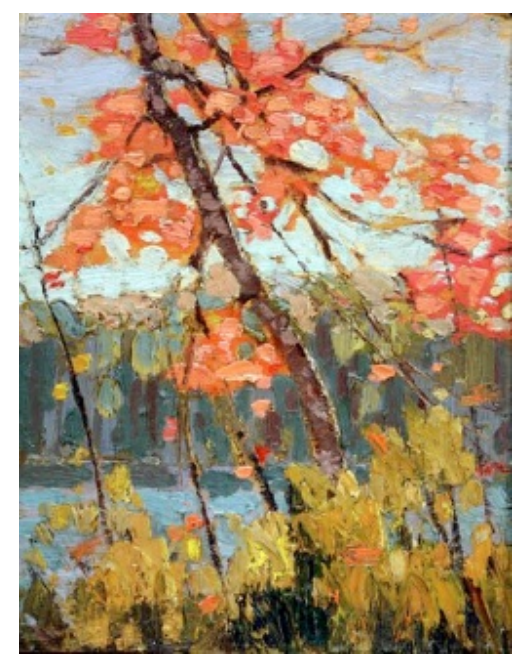

Figure 6. Twisted maple (Source: Tom Thomson, 1914) (Bing).

Thomson's best-known works The Jack Pine and The West Wind, both 1917 studio works, utilize the singletree motif set against a middle-distance landscape. In the Jack Pine painting (see Figure 7), Thomson combines the Art Nouveau-like tendrils with bands of color for the sky and reflecting water, which recalls pointillism with the modular gradation of color/light. It is interesting that in this large studio oil $(128 \mathrm{~cm} \times 140$ $\mathrm{cm}$ ), the painter commented that he struggled with the sky ${ }^{3}$ (Causey, 1981; Murray, 1999), which followed a gradation of bands as opposed to the quick approach of plein air painting. If Thomson eventually came to combine site material with current modern styles, his most important contribution to interpreting wilderness landscape was his firsthand experience of having to simplify a scene with a bold design that had the effect to heighten nature beyond the recording approach of naturalism. It would be in Thomson's "boards" that Canadians would come to see their country through the tree motif that spoke of northern wilderness and an icon of Canadian.

Unlike Monet, who used the motif to work in a series to study light change, Thomson used his plein air experience to create a one-off sketch that might be formulated in a studio work. Most of the field paintings of Thomson were never realized in a larger studio oil, but ended up in the National Gallery of Canada after the artist's early death on 8 July 1917, at Canoe Lake. On one wall the gallery displays the sketches; many reveal the tree motif that focused painting on decorations fashioned from the landscape of Canada's north.

\footnotetext{
${ }^{3}$ The problem of painting the sky in modern landscape was identified in a review of the English painter Harold Gilman, "A problem facing the Post-impressionist painter who wants to remain close to nature, but also to maintain a unity of pictorial effect, was to prevent the sky from seeming insubstantial compared with the foreground. Gilman's solution was to paint the sky in parallel bands of thick pigment which stand for forward of the landscape when the two meet at the horizon".
} 


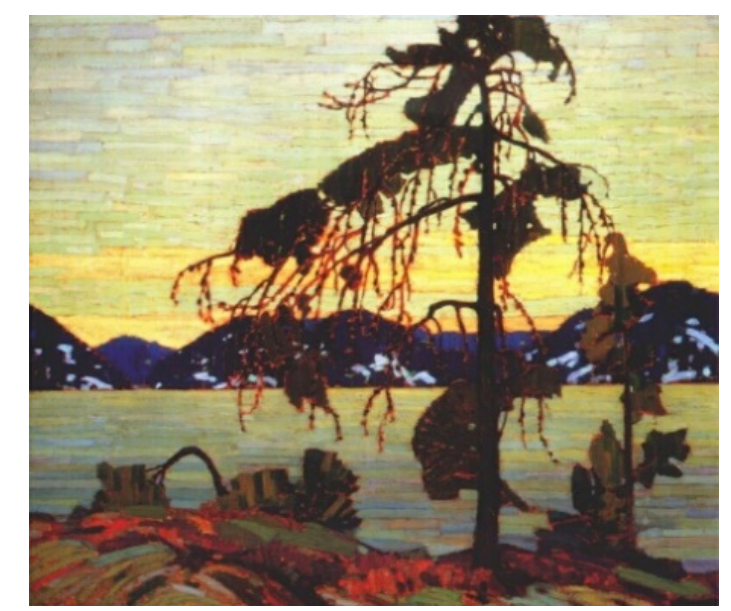

Figure 7. The Jack Pine (Tom Thomson, 1916-1917) (Bing).

\section{Pyramid Rising}

It was perhaps significant that Lawren Harris growing up in a wealthy Ontario family had both of his grandfathers and two uncles as church ministers. Indeed, the entire family reflected the Protestant ethic of Orange Ontario in the late 1990s. While Harris did not follow the family interest into business (farm machinery) or formal religion, he did show an interest in music and art as he went off to Berlin for studies in 1904. His art training was formal, based on the tradition of classroom life drawing and practice with watercolor work out of doors in the vibrant German city. In Berlin, Harris would have attended the National Gallery of Berlin's exhibition "Recent Masters", which looked at art from 1775-1875. In this show was the German romantic Caspar David Friedrich, whose haunting and lonely seacoast scenes would have stirred the feelings of the individual against the vastness of nature. A theme Harris would pursue in his Lake Superior landscapes of the 1920s.

Harris returned to Toronto in 1908 and helped found and build the Arts and Letters Club as he moved to the center of Toronto culture. Theatre manager Roy Mitchell had come back from New York to direct the Hart House at the University of Toronto and introduced Harris to Plato and theosophy. ${ }^{4}$ Theosophy was an Eastern-based religion/philosophy founded in New York in 1875 by Russian immigrant Helena Blavatsky ${ }^{5}$ (Kandinsky, 1912).

Blavatsky had lived in India and used essential truths of Eastern religions combined with Western beliefs systems to develop theosophy as a "Wisdom-Religion" whose organization would reveal "hidden truths" to its new members after joining the society (Blavatsky, 1889). Theosophy had at its core the interest in improving the individual along with society beyond ethic or cultural lines. Blavatsky believed that man had in him the "divine spark" but this knowledge was impaired from realization "owing to the impediments of matter" (Blavatsky, 1889, p. 19). To allow the soul to develop towards "goodness", one had to overcome these earthly distractions to develop to a higher plane. For a landscape painter, this everyday distraction of the material world might be reduced if one's pictures eschewed local detail for a more general presentation of the larger world.

\footnotetext{
${ }_{5}^{4}$ Mitchell was a member of the Theosophy Society of Toronto that stills exists.

5 Kandinsky referred to Mme. Blavatsky's Theosophical Society as issuing in answers to the spiritual world of modern man. Blavatsky's 1889 London publication The Key of Theosophy is quoted: "The new torchbearer of truth will find the minds of men prepared for his message, a language ready for him in which to clothe the new truth he brings, an organization awaiting his arrival, which will remove the merely mechanical, material obstacles and difficulties from his path". See p. 22.
} 
The first modern artist to formally combine theosophy with art was Wassily Kandinsky. In his publication, Concerning the Spiritual in Art (1911), Kandinsky offered a guide to those wishing to transcend the material world to feed the soul with art. He does this in two main ways: form and color. The most spiritual shape according to Kandinsky was the triangle, which attempted to "reach to heaven" (Kandinsky, 1912, p. 29). Here, the reference to going beyond art of the imitation of nature would be at the heart of this advice to artists.

This position on the need of art to suggest the spiritual can be traced back to Plato's The Republic where he observed that "one must watch out for the presence of small-mindedness. Nothing stops a mind constantly striving for an overview of the totality of things human and divine more effectively than involvement in petty details" (Plato, 1993, p. 205). Harris suppressed his "details" when he went to paint his monumental works on Lake Superior for the basis of geometry as revealed in the landscape. We can see from a sketch he made of a mountain in the Yoho Valley that he reduced the scene to its essentials of form and of color. His notes reveal basic color choices in yellow, green, and blue for the peak and glacier he gave the name "Isolation" mountain (Christensen, 2000) (see Figure 8). The sketch began the editing process by reducing the scene to basic shapes and colors that the studio oil would refine. He wrote in his papers in 1920, "Visible nature is but a distorted reflection of a more perfect world and the creative individual viewing her many garments, that which is timeless and entirely beautiful" (Christensen, 2000, p. 17). Here, the language was decidedly ideal beyond the material distractions of landscape of detail that might impair seeing the greater aspects of nature. The singular mountain became a favorite motif of Harris.

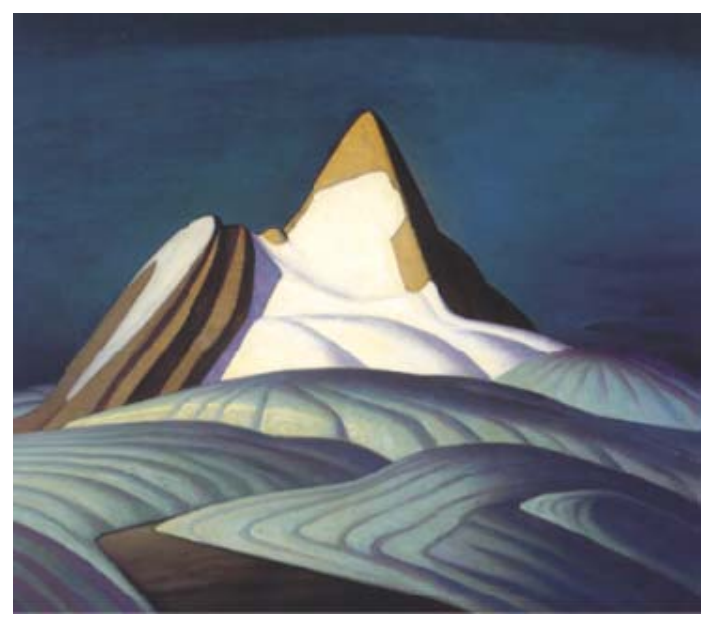

Figure 8. Isolation Peak (Lawren Harris, 1930) (Bing).

For Lawren Harris, the post-war years would be occupied with an attempt to seek the spiritual before nature. Harris joined the Toronto Theosophical Society in March of 1924 and published "Revelation of Art in Canada" in The Canadian Theosophist in 1925 (Murray, 2003, p. 57). Murray described the degree the artist had been taken by the subject, "He read papers at conventions and gave radio talks on the subject. He bothered his friends by zealously handing out or sending them literature about the society" (Murray, 2003, p. 42). The mid 1920s became the period of confirmation for Harris of his adopted faith and spiritual approach to painting that took Canadian landscape to abstraction that had not been seen before.

What Harris achieved in his landscape in the 1920s was the separation of nature into its constituent parts so that each region or area could reveal its shape and color in an obvious way. The author believes he 
represented the lower realms as the material world from which the soul sought to rise to the upper regions. In those wilderness places of vastness, such as the Great Lakes or the Canadian Rockies, these features revealed themselves unencumbered in their ability to represent clear ideas that might be translated to a theosophist explanation of the cosmos.

In the 1922 painting Above Lake Superior (see Figure 9), Harris made a direct statement on the earthbound world of the mountain striving for perfection at its peak and trees like anxious souls looked to convene with the amorphous clouds floating unencumbered in the spirit ether. Kandinsky wrote that the spirit was represented by the triangle where it "is moving slowly, almost invisibly forwards and upwards" (Kandinsky, 1912, p. 15). For Harris this "triangle" or process of moving upward was forever formed in the mountain, which for him became the pyramid rising into the upper regions, those regions of the "heavenly blue".

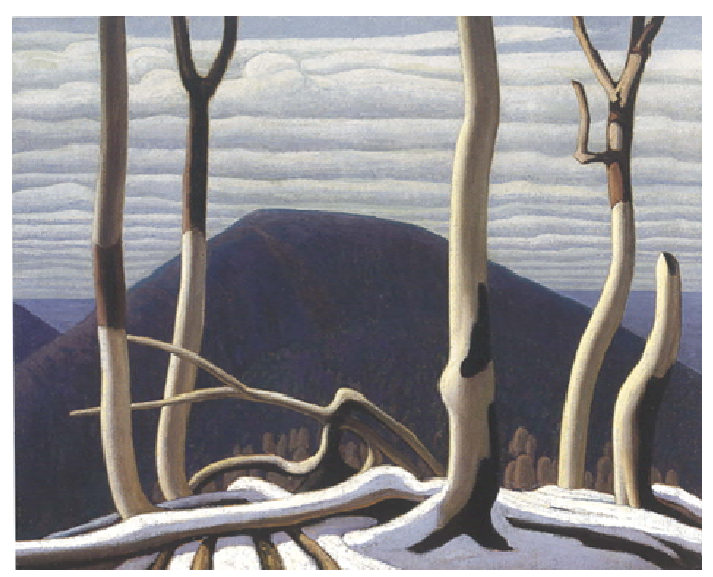

Figure 9. Above Lake Superior (Source: Lawren Harris, 1922) (Bing).

\section{Rhythmic Vitality}

A. Y. Jackson, from Montreal, went to study in Paris before he joined the Canadian War Memorials scheme in 1918. Jackson lamented that the Impressionist style he had picked up in Paris felt out of place in world war where patches of color could not carry the tragedy of the event. At the turn of the century, there had been developing an increase interest in the art of Asia. In Paris, Japanese woodblock prints were collected by artists and English writers showed an interest to comment on Oriental art. Laurence Binyon ${ }^{6}$ published his much read The Flight of the Dragon, London, 1911. The key elements of Chinese art were laid with rhythmic vitality, the first essential to making art.

It is very likely Jackson would have been aware of the book and certainly, after his stay in Paris he would have seen the Asian art. At some point, he seems to have moved from the petite patches of Impressionism for a wider rhythmic swing to his compositions. The Quebec landscape on the 1920 and 1930s reveal that the unity or rhythm to the painting came from his passions for displaying curves over the surface.

\footnotetext{
${ }^{6}$ Binyon started working for the British Museum in 1893.
} 


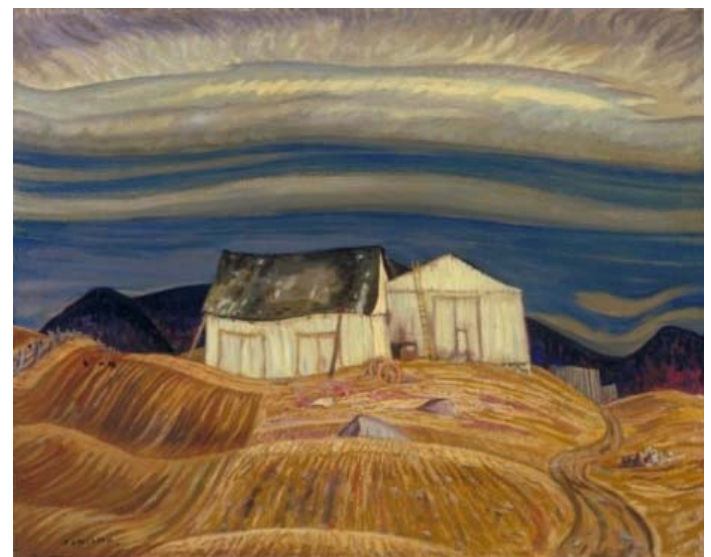

Figure 10. A Quebec farm (A. Y. Jackson, 1913) (Bing).

This became Jackson's trademark, or motif, as he dashed off landscapes from Quebec (see Figure 10) to Alberta and the North. This rhythm, this flow of line set the tone and became the music of his painting fostering a link between the Asian seeking for the life force that made the painting come alive. Like Thomson with his trees, or Harris with his mountains, Jackson found his style, his motif in the larger idea of rhythm that spoke to the "movement of life" that was so key to Eastern art.

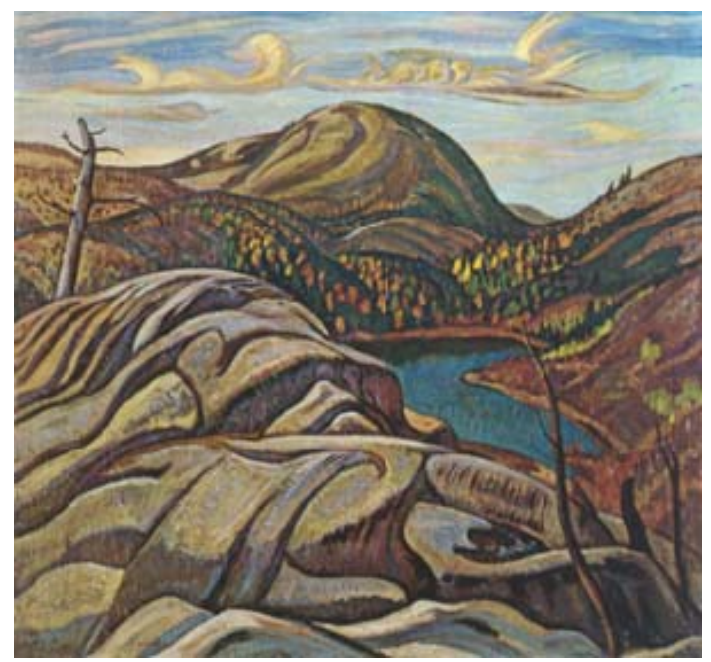

Figure 11. Nellie Lake (A. Y. Jackson, 1933) (Bing).

\section{Conclusion}

Canadian landscape painting became tied to European models and those ideas associated with design and the essence or art. Approaches to abstraction had been worked out with the impressionists who offered the idea that landscape painting could focus on a subject under different lighting conditions or reflect the artist's temperament before accurate recording of nature. The Canadian painters applied the offering of the subjective response, which modern art valued above the academy experience. Thomson learned these new ideas, such as combining complementary colors, through his acquaintance with his fellow painters, but it was his eye for the bold design that carried his pictures - he could fix the motif, the tree in a presentation that made art out of nature. Harris eased into sublimity with his barren mountain rocks, which reached up to hope in the heavens-a hope that humanity needed after the crushing First World War. Jackson, made music with his brush as it danced 
across the faces of so many destinations (see Figure 11). Rhythm in landscape painting became a motif in itself as it spoke to the essence of life viewed. Each painter internalized the freedom of modernity and gave us new interpretations of what would become known as the Canadian landscape.

\section{References}

Binyon, L. (1911). The flight of the dragon. London: John Murray.

Blavatsky, H. P. (1889). The key to theosophy. Retrieved from http://www.fileD:|20Theosophy20H_P_Blavarsky.htm

Causey, A. (1981). Harold Gilman: An Englishman and post-impressionist. In Harold Gilman 1876-1919 (p. 12). London: Art Council of Great Britain.

Christensen, L. (2000). A hiker's guide to the rocky mountain art of Lawren Harris. Calgary: Fifth House.

Jackson, A. Y. (1967). A painter's country: The autobiography of A. Y. Jackson. Toronto: Clark, Irwin.

Kandinsky, W. (1912). Concerning the spiritual in art. (M. Sadler, Trans.). New York, NY: Kessinger.

Murray, J. (1999). Tom Thomson: Trees. Toronto: McArthur \& Co.

Murray, J. (2003). Lawren Harris: An introduction to his life and art. Toronto: Firefly Books.

Plato. (1993). The republic. (R. Waterfield, Trans.). Oxford: Oxford University Press.

Town, H., \& Silcox, D. P. (1977). Tom Thomson: Silence and the storm. Toronto: McClelland and Stewart. 